С.В. Женжера, А.В. Литвин, А.А. Бровко

Харківський національний університет Повітряних Сил ім. І. Кожедуба, Харків

\title{
УДОСКОНАЛЕННЯ СИСТЕМИ ОХОРОНИ ВІЙСЬКОВИХ ОБ'ЄКТІВ ШЛЯХОМ РОЗРОБКИ ЗАСОБІВ РАДІОЕЛЕКТРОННОЇ БОРОТЬБИ ДЛЯ ПРОТИДІЇ БПЛА
}

Для покращення системи охорони військових об'єктів (особливо складів артилерійського озброєння) від ударних дій БПЛА запропоновано використання малопотужних постановників завад для придушення каналу управління ними. У процесі роботи були розраховані зони надійного управління $і$ зони придушення каналу управління БПЛА для обгрунтування мінімальних потужностей постановника завад на прикладі охорони складу РАО з периметром території 1200 м. Відповідно до розрахунків запропонована принципова схема 5-ти канального постановника завад для протидії БПЛА з потужністю випромінювання 5 Вт, вартість якого значного дешевше промислових аналогів.

Ключові слова: радіоелектронна боротьба, безпілотний літальний апарат, придушення каналу управління, охорона військових об'єктів.

\section{Вступ}

Постановка проблеми. 3 початку проведення операції Об'єднаних сил (ООС) відбулися 4 великі пожежі на складах РАО: 2015 р. - м. Сватово; 2017 р. - м. Балаклея і с. Калинівка; 2018 р. - с. Ічня. Однією з основних версій виникнення пожеж - є диверсії з використанням безпілотних літальних апаратів (БПЛА). Приведення великої чисельності систем охорони військових об'єктів до сучасних вимог (у тому числі встановлення промислових засобів РЕБ для протидії БПЛА) вимагає залучення не підйомних обсягів фінансування. Тому існує необхідність у розробці малопотужних та малобюджетних постановників завад каналам управління БПЛА (в першу чергу тих, які знаходяться у вільному продажу).

Аналіз останніх досліджень і публікацій. Питання сучасного стану, досвіду бойового застосування, та подальшого розвитку безпілотної авіації в умовах зміни форм і способів ведення збройної боротьби вітчизняними науковцями досліджені в роботах [1-3]. При цьому питання методів протидії БПЛА 3 наданням рекомендацій щодо захисту військових об'єктів потребують більш детального освітлення.

Мета статті - підвищення можливостей протидії надлегким БПЛА при охороні військових об’єктів за допомогою розробки малопотужного постановника завад.

\section{Виклад основного матеріалу}

Аналіз останніх військових конфліктів свідчить про інтенсивний розвиток та використання системи обміну інформації. Важливу роль в цій системі займають безпілотні літальні апарати. Безпілотна авіація часто є джерелом первинної інформації для різ- номанітних сил вогневого ураження, широко використовується для коректування засобів вогневого ураження, дозволяє забезпечити управління й оперативну взаємодію всіма ресурсами. Бойовий досвід застосування БПЛА, в першу чергу США і Росією, показав високу ефективність цих засобів розвідки. 3 цієї причини в зоні проведення ООС Збройні Сили України (ЗСУ) зіткнулися з широким застосуванням БПЛА незаконними військовими формуваннями (НВФ). Конфлікт на сході України змусив скоригувати пріоритети розвитку військової техніки. Починаючи з 2014 року ПС України почали широко використовувати БПЛА в зоні проведення ООС. Це призвело до значного збільшення ефективності бойових операцій і дозволило знищити значну кількість сил і засобів НВФ. Однак в даний час збройні сили України зіткнулися з частими випадками втрати контролю і управління над своїми БПЛА. Основною причиною цих випадків є застосування спеціальних засобів моніторингу частотного діапазону, створення інформаційних перешкод і перехоплення безпілотних апаратів. В результаті БПЛА ПС України не тільки знищують вогневими засобами, но і в деяких випадках, підрозділам НВФ вдається посадити безпілотні засоби на підконтрольній території і після перекодування використовувати в своїх цілях. Ситуація, що склалася свідчить про необхідність розробки сучасних засобів протидії станціям радіотехнічної розвідки і радіоелектронної боротьби, а також розробки методів і засобів знищення БПЛА.

В зоні проведення операції Об'єднаних сил на Сході України продовжуються польоти безпілотних літальних апаратів для ведення розвідки в інтересах артилерійських підрозділів як незаконних збройних формувань так і підрозділів російських збройних сил. Відомі факти, коли після обльоту БПЛА через 
нетривалий час були здійснені обстріли позицій підрозділів Збройних Сил України з артилерійського та танкового озброєння. Виходячи 3 цього боротьба 3 БПЛА являється одним із пріоритетних завдань.

Особливістю операції Об'єднаних сил на Сході нашої країни стало активне застосування протиборчими сторонами безпілотних авіаційних комплексів. Таке обопільне використання сучасних безпілотників під час бойових дій трапляється чи не вперше в історії локальних війн та збройних конфліктів.

Починаючи з 2014 року в небі Донбасу, крім найпростіших саморобних квадрокоптерів, фіксували нові безпілотні авіаційні комплекси різних класів вітчизняного й іноземного виробництва та серійні зразки, які є на озброєнні армії Російської Федерації.

Протягом семи років війни, у зоні проведення операції Об'єднаних сил українськими військовими, спецпризначенцями та особовим складом національної гвардії використовувались безпілотні авіаційні комплекси (БПАК), які можна розділити на три групи:

- комплекси вітчизняного виробництва, які були закуплені за державним оборонним замовленням у 2015 році і нині знаходяться на підконтрольній експлуатації в зоні ООС, або перебувають у арсеналах військових частин. У подальшому ці комплекси можуть бути прийняти на озброєння (постачання) Збройних Сил;

- комплекси зарубіжного виробництва, які були закуплені силовими відомствами за державні гроші, або поставлені в рамках військово-технічної допомоги;

- безпілотні апарати і комплекси, які були виготовлені, закуплені і передані в силові відомства волонтерами та спонсорськими організаціями.

Провідні країни всього світу останніми роками активно працюють у напрямку розвитку дистанційно керованих систем озброєння. В авангарді цих робіт йдуть безпілотні літальні апарати. Звичайно, БПЛА мають деякі мінуси, але відносна дешевизна, зручність використання та мінімальний вплив людського фактора, схиляють військових до вибору саме цієї техніки. Аналізуючи проведення останніх воєнних конфліктів можна зробити висновок, що безпілотні літальні апарати зарекомендувала себе, як надійний i ефективний засіб ведення розвідки, нанесення ударів по об'єктах противника і виконання деяких інших завдань. За деякими оцінками, тільки в США за останні 15 років було вироблено понад 30 тис БПЛА різних класів і типів, велика частина яких використовується військовими і спецслужбами.

Низькі значення показників ефективності ураження малорозмірних БПЛА активними зенітними засобами обумовлюють необхідність розробки і проведення комплексу спеціальних заходів щодо організації їх ураження активними засобами, а також проведення ряду заходів з протидії системам розвідки і вогневого придушення, наявними на борту БПЛА.

Таким чином, знищення або захоплення техніки противника, з різною ймовірністю, можливі вже при нинішньому розвитку озброєнь і військової техніки. 3 точки зору вартості, простоти застосування та ефективності охорони складів доцільно застосовувати генератори завад.

Найчастіше для управління БПЛА використовуються частоти близько 2,4 ГГц, що належать до Wi-Fi діапазону стандарту $802.11 \mathrm{~b} / \mathrm{g} / \mathrm{n}$. Також використовується частоти 5,8 ГГЦ, на яких забезпечується передача відео зображення з борту безпілотного літального апарату на землю. Недоцільно придушувати частоту 5,8 ГГц, яка призначена для передачі відеоінформації, тому що безпілотник може керуватися за датчиками сигналів GPS і може продовжувати політ. Доцільніше придушувати канал телеуправління 2,4 ГГц, тому що це порушить управління безпілотним літальним апаратом і він повинен буде або зійти з маршруту, або повернутися назад по заздалегідь підготованому маршруту, у відповідності до моделі безпілотного літального апарату. Тому у подальшій роботі будемо розглядати придушення каналу телеуправління на частоті 2,4 ГГц, Wi-Fi стандарту 802.11.b/g/n.

На початку проведення АТО ситуація в цій сфері була найбільш плачевною. Тоді техніка, яка була на озброєнні підрозділів РЕБ, не відповідала вимогам часу. До того ж значна іiі частина була несправною. 3 усіх підрозділів, які були на той час, вдалося сформувати лише два батальйони та дві роти радіоелектронної боротьби зі справною технікою.

Не зважаючи на захоплення НВФ у 2014 році донецького заводу “Топаз", виробника сучасних комплексів РЕБ “Кольчуга" та "Мандат" всі технології по виготовленню сучасних засобів РЕБ були збережені, і найближчим часом українська промисловість на базі науково-виробничого комплексу "Iскра" готова буде розпочати виробництво модернізованих комплексів із поліпшеними характеристиками. Отже ми можемо зробити висновки, що системи РЕБ не доцільно використовувати в кожному підрозділі, через їх габаритність і тому далі буде запропоновано розробку малогабаритної, малопотужної портативної системи постановника завад. 3 урахуванням широкого використання БПЛА в у зоні проведення операції Об'єднаних сил, доцільно та актуально розглянути схему постановника завад, яку було розроблено і обгрунтовано на основі генератора, що управляється напругою. Основу оцінки ефективності роботи засобів радіозв'язку в умовах завад складає порівняння (зіставлення) частотних, просто- 
рових, тимчасових та енергетичних можливостей засобів радіоелектронного придушення з аналогічними характеристиками засобів зв'язку своїх військ. Таке зіставлення робиться $з$ урахуванням фізикогеографічних умов, рельєфу місцевості, метеоумов, пори року, й інших факторів.

Частотні можливості засобів радіоелектронної розвідки і радіоелектронного придушення аналізується шляхом зіставлення діапазону їхньої роботи 3 діапазоном роботи засобів радіозв'язку. За наявності ділянок діапазону, що перекривається, можна зробити висновок про можливість ведення радіоелектронної розвідки і створення завад у даній ділянці діапазону.

Просторові можливості по придушенню істотно залежать від глибини розгортання станцій завад у смузі бойових дій, а також діапазону частот. Глибина розгортання засобів радіоелектронного придушення визначається належністю до тактичної чи оперативної ланки управління. Під час оцінки просторових можливостей засобів радіорозвідки і подавлення провідним $є$ розуміння забезпечення електромагнітної доступності радіоліній, що придушуються. У діапазоні УКХ

$$
D_{\text {емд }}=4,12\left(\sqrt{H_{\text {a.c.з. }}}+\sqrt{H_{\text {a.p. }}}\right)(\kappa M),
$$

де $H_{\text {a.c.з. }}$ - висота підйому антени станції завад, (м);

$H_{a . p .}$ - висота підйому антени радіостанції, що забезпечує зв'язок, (м).

Оцінити ступінь впливу завад і ефективність роботи радіопристроїв дає можливість зіставлення енергетичних показників радіостанції і станції завад. Вплив радіолінії проявляється в ускладненні прийому корисної інформації. Це відбувається за рахунок того, що в будь-якій точці прийому крім поля передавача радіолінії з'являється поле станції завад. Імовірність надійного прийому корисної інформації $\left(P_{\text {н.n. }}\right)$ залежить від відношення напруги корисного сигналу до напруги сигналу завади на вході приймача. Енергетичні показники завадостійкості радіоліній оцінюється виходячи з умови забезпечення співвідношення рівня корисного сигналу до рівня завад.

Мінімальне відношення сигнал/завада за напругою на вході приймача, при якому забезпечується надійний прийом із заданою ймовірністю, називається коефіцієнтом надійного прийому $q_{н . n}$

$$
q_{\text {н.n. }}=\left|\frac{U_{c}}{U_{3}}\right|, \text { для } P_{\text {H.n. }}=\text { const. }
$$

Числове значення коефіцієнта надійного прийому $\left(q_{н . n}\right)$ залежить від радіолінії, виду сигналу завади і заданої ймовірності надійного прийому $P_{\text {H.n. }}$ в умовах завад. Значення $q_{\text {н.n }}$ можна вважати нормою завадозахищеності різних видів зв'язку. У табл. 1 наведені чистові значення $\left(q_{H . n}\right)$ (для ймові- рності надійного прийому $P_{H . n .} \geq 0,8$ ) для різних видів зв'язку, що дозволяють з достатньою для оперативно-тактичних розрахунків точністю визначити зони надійного прийому в умовах завад.

Таблиця 1

Значення коефіцієнтів надійного прийому для різних видів зв'язку

\begin{tabular}{|c|c|}
\hline Вид зв'язку & $\begin{array}{c}\text { Коефіцієнт } \\
\text { надійного } \\
\text { прийому }\end{array}$ \\
\hline Телефонний незасекречений & $1,5 \ldots 2$ \\
\hline Телефонний засекречений & 5 \\
\hline Телеграфний слуховий & 1 \\
\hline Передача даних по Wi-Fi & 5 \\
\hline $\begin{array}{c}\text { Телеграфний букводрукуючий } \\
\text { незасекречений }\end{array}$ & 7 \\
\hline $\begin{array}{c}\text { Телеграфний букводрукуючий } \\
\text { засекречений }\end{array}$ & 10 \\
\hline Передача даних & 10 \\
\hline
\end{tabular}

Джерело: розроблено авторами.

Зона надійного прийому інформації зі заданою ймовірністю характеризується коефіцієнтом надійного прийому і співвідношенням енергетичних потенціалів станції завад та радіостанції корисного сигналу і визначається як енергетичний коефіцієнт $K$

$$
K=q_{H . n .} \sqrt{\frac{A_{n .3}}{A_{c}}},
$$

де $A_{n .3 .}-$ енергетичний потенціал станції завад, який дорівнює

$$
A_{n .3}=P_{n .3} \cdot G_{c} \frac{\Delta f_{c}}{\Delta f_{3}} K_{n},
$$

де $P_{n .3}-$ потужність передавача завад, Вт;

$G_{c}$ - коефіцієнт підсилення антени станції завад, дБ;

$\Delta f_{c}-$ спектр сигналу завади, МГц;

$\Delta f_{3}-$ смуга пропускання частот приймача, МГц;

$K_{n}$ - коефіцієнт, що враховує поляризацію поля корисного сигналу і завад;

$A_{c}$ - енергетичний потенціал станції корисного сигналу (станції зв’язку), що визначається за формулою

$$
A_{c}=P_{c} \cdot G_{c}
$$

де $P_{c}$ - потужність передавача радіостанції ,Вт;

$G_{c}$ - коефіцієнт підсилення антени станції корисного сигналу (станції зв'язку).

У тих випадках, коли передавачі радіостанції і станцій завад мають антени направленої дії $\left(\mathrm{G}_{\mathrm{c}}=\mathrm{G}_{3}\right)$ з однаковою поляризацією $\left(\mathrm{K}_{\Pi}=1\right)$, а 
завада є прицільною і збігається за спектром зі смугою пропускання частот приймача $\left(\Delta \mathrm{f}_{\Pi}=\Delta \mathrm{f}_{\mathrm{c}}\right)$, формула (3) може мати вигляд

$$
K=q_{H . n} \sqrt{\frac{P_{H . n}}{P_{c}}} .
$$

Енергетичний коефіцієнт “ $K$ ” визначає конфігурацію зони надійного прийому. Залежно від чисельного значення $K$ конфігурація зони надійного прийому виглядає по різному. Розглянемо три можливі випадки.

a) при $K<1$ зона надійного прийому із заданою ймовірністю існує у всій зоні дії передавача корисного сигналу за винятком зони завад навколо станцій завад.

Зона завад (придушення) являє собою коло радіусом

$$
R_{n}=D_{0} \frac{K}{1-K^{2}}(\kappa M),
$$

де $D_{0}-$ відстань між станцією завад і станцією зв'язку, км;

У даному випадку центр цього кола зміщений за станцію завад по лінії "радіостанція-станція завад" на величин $a_{n}=R_{n} \cdot K$;

б) при $K>1$ зона надійного прийому із заданою ймовірністю являє собою коло радіусом $R_{H . n}$

$$
R_{H . n}=D_{0} \frac{K}{K^{2}-1}(\kappa M),
$$

центр якого зміщений за станцію корисного сигналу на величину

$$
a_{H . n}=\frac{R_{H . n}}{K}(\kappa M),
$$

в) при $K=1$ межі зони завад і зони надійного прийому проходять через середину відстані між станцією завад і станцією зв'язку.

Далі приведено розрахунки зони надійного прийому. Для цього спочатку розрахуємо енергетичний коефіцієнт К за формулою (6). Вихідні дані для розрахунку:

- коефіцієнт надійного прийому $q_{н . n}-5$;

- питома потужність станції завад на кожний Wi-Fi канал - 0,36 Вт;

- потужність сигналу від пульта управління БПЛА - 1 Вт;

$$
K=5 \cdot \sqrt{\frac{0,36}{1}=3} .
$$

В результаті розрахунків отримали значення енергетичного коефіцієнту $K>1$, звідси маємо, що зона надійного прийому із заданою ймовірністю $P_{\text {H.n. }}=0,8$ являє собою коло радіусом, яке розрахували за допомогою формули (8). Вихідні дані для розрахунку:

- відстань між станцією завад і пультом управління $D_{0}=200 \mathrm{M}$;

- енергетичного коефіцієнт $K=3$;

$$
R_{H . n}=0,2 \frac{3}{9-1}=0,075 \mathrm{~km} ;
$$

центр якого зміщений за станцію корисного сигналу на величину

$$
a_{H . n}=\frac{0,075}{3}=0,025 \kappa \mu .
$$

Як результат розробили схему, яка зображена на рис. 1.

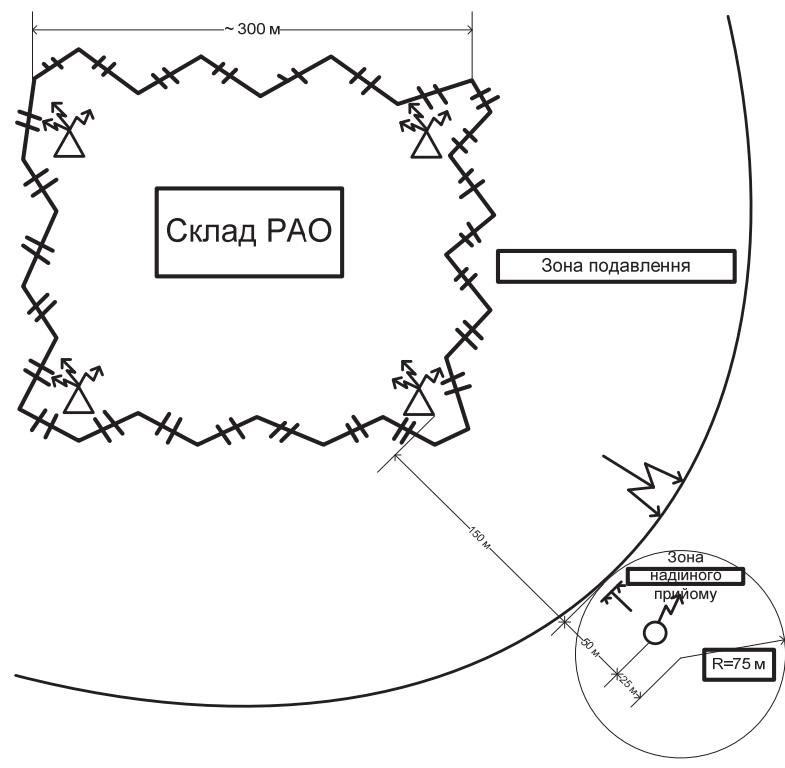

Рис. 1. Зона подавлення каналу управління Джерело: розроблено авторами.

Дана схема наглядно показує надійність подавлення каналу управління БПЛА на частоті 2,4 ГГц. При збільшенні території охороняємих об'єктів можливо збільшити кількість станцій завад, замість чотирьох можливо буде ставити шість, вісім станцій, в залежності від конфігурації периметру. Відповідно до проведених розрахунків за допомогою фо-

\begin{tabular}{|c|c|c|c|c|c|c|}
\hline & R1 & R2 & R3 & R4 & R5 & R6 \\
\hline $\begin{array}{l}\begin{array}{l}\text { Коефіпіент надійного } \\
\text { прийому }\end{array} \\
\end{array}$ & 5 & 5 & 5 & 5 & 5 & 5 \\
\hline \begin{tabular}{|l|} 
Загамьна потужність \\
станції завад, Вт
\end{tabular} & 5 & 2 & 1 & 5 & 2 & 1 \\
\hline 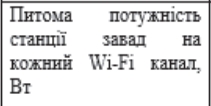 & 0,36 & 0,14 & 0,07 & 0,36 & 0,14 & 0,07 \\
\hline $\begin{array}{l}\text { Потужність сигналу } \\
\text { від пульта управління } \\
\text { БПЛА, Вт } \\
\end{array}$ & 1 & 1 & 1 & 0,1 & 0,1 & 0,1 \\
\hline \begin{tabular}{|lll} 
Відстань між станщіею \\
завад i & станщіею \\
зв'язку, м & \\
\end{tabular} & $50 \ldots 200$ & $50 \ldots 200$ & $50 \ldots 200$ & $50 \ldots 200$ & $50 \ldots 200$ & $50 \ldots 200$ \\
\hline $\begin{array}{l}\text { Енергетичний } \\
\text { коефіпіент }\end{array}$ & 3 & 1,9 & 1,3 & 9,5 & 6 & 3,5 \\
\hline
\end{tabular}
рмули (7) та (8) було побудовано графіки залежності зони надійного прийому від дальності до пульта управління безпілотним літальним апаратом.

Таблиця 2

Вихідні дані для розрахунків з використанням Wi-Fi діапазону 2,4 ГГц

Джерело: розроблено авторами. 


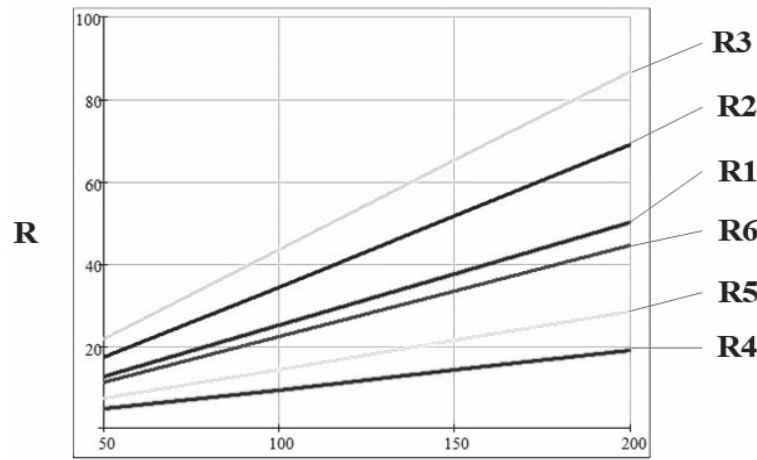

D

Рис. 2. Залежність зони надійного прийому від відстані між станцією завад і станцією зв’язку Джерело: розроблено авторами.

У результаті розрахунків з різними діапазонами частот каналу управління при відстані до пульта управління БПЛА 50 метрів та при відстані до пуль- та управління 200 метрів, дійшли до висновку, що зона подавлення відповідає вимогам до охорони всього периметру типових складів РАО, тому доцільно використовувати такий пристрій при охороні об'єктів.

\section{Висновки}

В даній роботі пропонується використовувати постановник завад 3 потужністю 5 Вт та розташовувати їх по периметру складів, згідно графіків залежності зони надійного прийому від відстані між станцією завад і пультом управління безпілотним літальним апаратом.

3 аналізу графіку витікає, що постановники завад потужністю менше 5 Вт недоцільно використовувати через те, що потрібно буде більша кількість генераторів завад на той самий периметр охороняємого складу та в деяких випадках зона подавлення занадто мала.

\section{Список літератури}

1. Корольов Р. В., Королюк Н. О., Петров О. В., Сюлев К. В. Аналіз сучасних засобів знищення безпілотних літальних апаратів : веб-сайт. URL: https://www.ukrmilitary.com/2017/10/zasoby-proty-bpla.html (дата звернення: 02.06.2021).

2. Бережний А. О., Крижанівський I. М., Барабаш О. В. Метод автоматизованого планування маршрутів безпілотних літальних апаратів з урахуванням виявлення стаціонарних об'єктів. Телекомунікаційні та інформаційні технологї. 2019. № 4(65). https://doi.org/10.31673/2412-4338.2019.049098.

3. Основні тенденції створення та застосування груп безпілотних літальних апаратів / Лупандін В. А. та ін. Наука $i$ техніка Повітряних Сил Збройних Сил Украӥни. 2019. № 2(35). С. 88-96. https://doi.org/10.30748/nitps.2019.35.11.

4. Малярчук М. В., Слюсар В. І. Перспективні інформаційні технології зв'язку з безпілотними літальними апаратами. Сучасні інформачійні технологї̈ у сфері безпеки та оборони. 2010. № 1(7). С. 48-52.

5. Трофимов Н. А., Пипия Л. К., Осипова О. Е. Основні логістичні функції БЛА при проведенні військових операцій. Наука за кордоном. 2012. № 12. С. 5-8.

6. Корченко А. Г., Ілляш О. С. Узагальнена класифікація безпілотних літальних апаратів. Збірник наукових праиъь Харківського університету Повітряних Сил. 2012. № 4(33). С. 27-36.

7. Камалтинов Г. Г., Колеснік О. М. Тенденції розвитку радіолокаційних засобів контролю повітряного простору. Збірник наукових праць Харківського національного університету Повітряних Сил. 2020. №2(64). С. 8995. https://doi.org/10.30748/zhups.2020.64.13.

8. Кушнір О. І., Давикоза О. П., Кучеренко Ю. Ф. Аналіз впливу “гібридної” війни на розвиток автоматизованої системи управління авіацією та ППО Збройних Сил України. Наука і техніка Повітряних Сил Збройних Сил України. 2017. № 2 (27). C. 116-120. https://doi.org/10.30748/nitps.2017.27.22.

9. Austin R. Unmanned aircraft systems: UAVS design, development and deployment. Boston : John Wiley \& Sons Ltd, 2010. P. 113-127. https://doi.org/10.1002/9780470664797.

10. Bradley S. Atmospheric acoustic remote sensing. CRC Press, Taylor \& Francis Group, 2008. - P. 90-91.

11. Sinibaldi G., Marino L. Experimental analysis on the noise of propellers for small UAV. Applied Acoustics. 2013. № 4. P. 79-88. https://doi.org/10.1016/j.apacoust.2012.06.011.

12. Saravanakumar A, Senthilkumar K. Exploitation of Acoustic signature of low flying Aircraft using Acoustic Vector sensor. Defence Science Journal. 2014. Vol. 74. No. 2. P. 95-98. https://doi.org/10.14429/dsj.64.3924.

\section{Відомості про авторів:}

\section{Женжера Сергій Володимирович}

кандидат технічних наук

старший викладач

Харківського національного університету

Повітряних Сил ім. І. Кожедуба,

Харків, Україна

https://orcid.org/0000-0001-6965-6890

\section{Information about the authors:}

\section{Sergey Zhenzhera}

Candidate of Technical Sciences

Senior Instructor

of Ivan Kozhedub Kharkiv

National Air Force University,

Kharkiv, Ukraine

https://orcid.org/0000-0001-6965-6890 


\section{Литвин Андрій Володимирович}

викладач

Харківського національного університету

Повітряних Сил ім. І. Кожедуба,

Харків, Україна

https://orcid.org/0000-0003-1962-6356

\section{Бровко Артур Анатолійович}

курсант

Харківського національного університету

Повітряних Сил ім. І. Кожедуба,

Харків, Україна

https://orcid.org/0000-0002-8434-9976

\author{
Andrii Lytvyn \\ Instructor \\ of Ivan Kozhedub Kharkiv \\ National Air Force University, \\ Kharkiv, Ukraine \\ https://orcid.org/0000-0003-1962-6356
}

\author{
Arthur Brovko \\ Cadet \\ of Ivan Kozhedub Kharkiv \\ National Air Force University, \\ Kharkiv, Ukraine \\ https://orcid.org/0000-0002-8434-9976
}

\title{
СОВЕРШЕНСТВОВАНИЕ СИСТЕМЫ ОХРАНЫ ВОЕННЫХ ОБЪЕКТОВ ПУТЕМ РАЗРАБОТКИ СРЕДСТВ РАДИОЭЛЕКТРОННОЙ БОРЬБЫ ДЛЯ ПРОТИВОДЕЙСТВИЯ БПЛА
}

\author{
С.В. Женжера, А.В. Литвин, А.А. Бровко
}

Для улучшения системы охраны военных объектов (особенно складов артиллерийского вооружения) от ударных воздействий БПЛА предложено использование маломощчных постановщчиков помех для подавления канала управления ими. В процессе работы были рассчитаны зоны надежного управления и зоны подавления канала управления БПЛА для обоснования минимальных мощностей постановщчика помех на примере охраны состава ракетно-артиллерийского вооружения с периметром территории 1200 м. Согласно расчетам, предложена принципиальная схема пяти канального постановщика помех для противодействия БПЛА с мощностью излучения 5 Вт, стоимость которого значительно дешевле промышленных аналогов.

Ключевые слова: радиоэлектронная борьба, беспилотный летательный аппарат, подавление канала управления, охрана военных объектов.

\section{IMPROVEMENT OF THE SYSTEM OF PROTECTION OF MILITARY FACILITIES BY DEVELOPING MEANS OF RADIOELECTRONIC COMBAT TO CONTROL UAVS}

S. Zhenzhera, A. Lytvyn, A. Brovko

Analysis of recent military conflicts shows the intensive development and use of information exchange systems. An important role in this system is played by unmanned aerial vehicles (UAVs). Unmanned aerial vehicles are often a source of primary information for various fire forces, are widely used to adjust the means of fire damage, allows you to ensure the management and operational interaction of all resources. Combat experience in the use of UAVs, primarily the United States and Russia, has shown the high effectiveness of these means of reconnaissance. For this reason, in the anti-terrorist operation zone, the Armed Forces of Ukraine (AFU) faced the widespread use of UAVS by illegal military formations (ILF). Since the beginning of Operation Allied Forces, there have been 4 major fires in missile and artillery depots: 2015 - the town of Svatovo; 2017 - the town of Balakleya, the village of Kalynivka; 2018 - the village of Ichnia. One of the main versions of fires is sabotage using UAVs. Bringing a large number of systems of protection of military facilities to modern requirements (including the installation of industrial means of electronic warfare to counter UAVS) requires the involvement of low-volume funding. Therefore, to improve the system of protection of military facilities (especially artillery depots) from the strike actions of UAVs (especially those that are in free sale), it is proposed to use a low-power jammer to suppress the control channel. As a result of calculations with different frequency bands of the control channel at a distance of 50 meters from the UAV and 200 meters from the control panel, we concluded that the suppression zone meets the requirements for protection of the entire perimeter of artillery depots, so it is advisable to use such a device military facilities. In this paper, it is proposed to use a noise generator with a power of $5 \mathrm{~W}$ and place them around the perimeter of the warehouses, according to the graphs of the zone of reliable reception on the distance between the noise station and the unmanned aerial vehicle control panel. The analysis of the graph shows that noise generators with a power of less than 5 watts should not be used because they will require more noise generators on the same perimeter of the protected warehouse and in some cases, the suppression zone is too small. According to the calculations, the schematic diagram of a 5-channel interference suppressor for counteracting UAVS with a radiation power of $5 \mathrm{~W}$, the cost of which is much cheaper than industrial analogues, is proposed.

Keywords: electronic warfare, unmanned aerial vehicle, suppression of the control channel, protection of military facilities. 